\title{
Funerary Rituals in Early Middle Ages: the Case of the Individual of the Tomb 57 of Vicenne-Campochiaro (VII C.)
}

\author{
G. Bocchini ${ }^{1}$, M.G. Belcastro ${ }^{1}$ \\ ${ }^{1}$ Laboratorio di Bioarcheologia e Osteologia Forense - Dipartimento di Biologia Evoluzionistica Sperimentale - Alma \\ Mater Studiorum - Università di Bologna, via Selmi 3, 40126 Bologna. E-mail: greta.bocchini@studio.unibo.ixt
}

KEYWORDS: Early Middle Ages, pathologies, funerary rituals, interpersonal violence.

\section{Introduction}

The medieval (640-670 AD) necropolis of VicenneCampochiaro is related to a nomadic Eurasian group identified with the Avars (cf. Belcastro et al., 2003).Among the 130 skeletons, we studied the skeleton of the grave 57 , because of some features of the burial (marginal position of the burial and superficial position of the skeleton) (Ceglia, personal communication) and the absence of parts of the skeleton (skull, patellae, some foot bones). Some pathological condition allowed us for hypothesizing interpersonal violence. All these features might indicate a case of anomalous burial (cf. Murphy, 2008; cf. Belcastro et al., 2003).

\section{Materials and Methods}

The map shows the marginal position of the tomb (Fig.1). The skeleton was in supine position. Restoration and anthropological study were conducted following

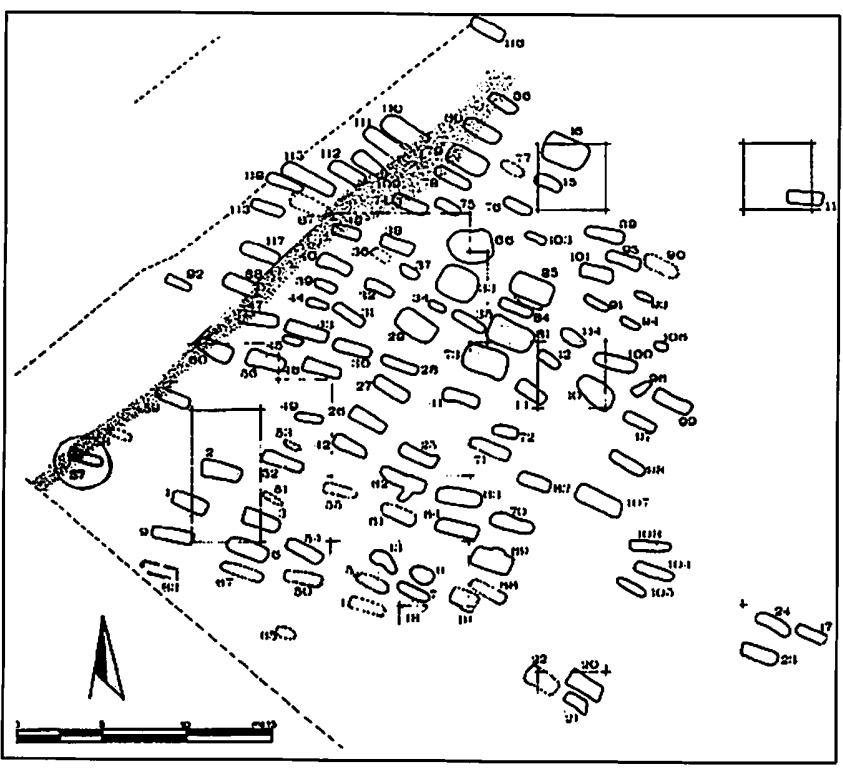

Fig. 1. Map of the necropolis: tomb 57 in red. the common anthropological methods (cf. Buikstra and Ubelaker, 1994). For age estimation the degree of sacral vertebral body fusion (Belcastro et al., 2008) was also studied.Also the paleopathological study was performed (cf. Fornaciari and Giuffra, 2009; Lovell, 1997).

\section{Results}

The skeleton, a young adult male (25-30 years old), lacked, in situ, of the skull, of all the phalanges of the left foot, of the intermediate (except hallucial intermediate phalange) and distal phalanges of the right foot, and of the patellae (Fig. 2), that could be intentionally taken away peri or

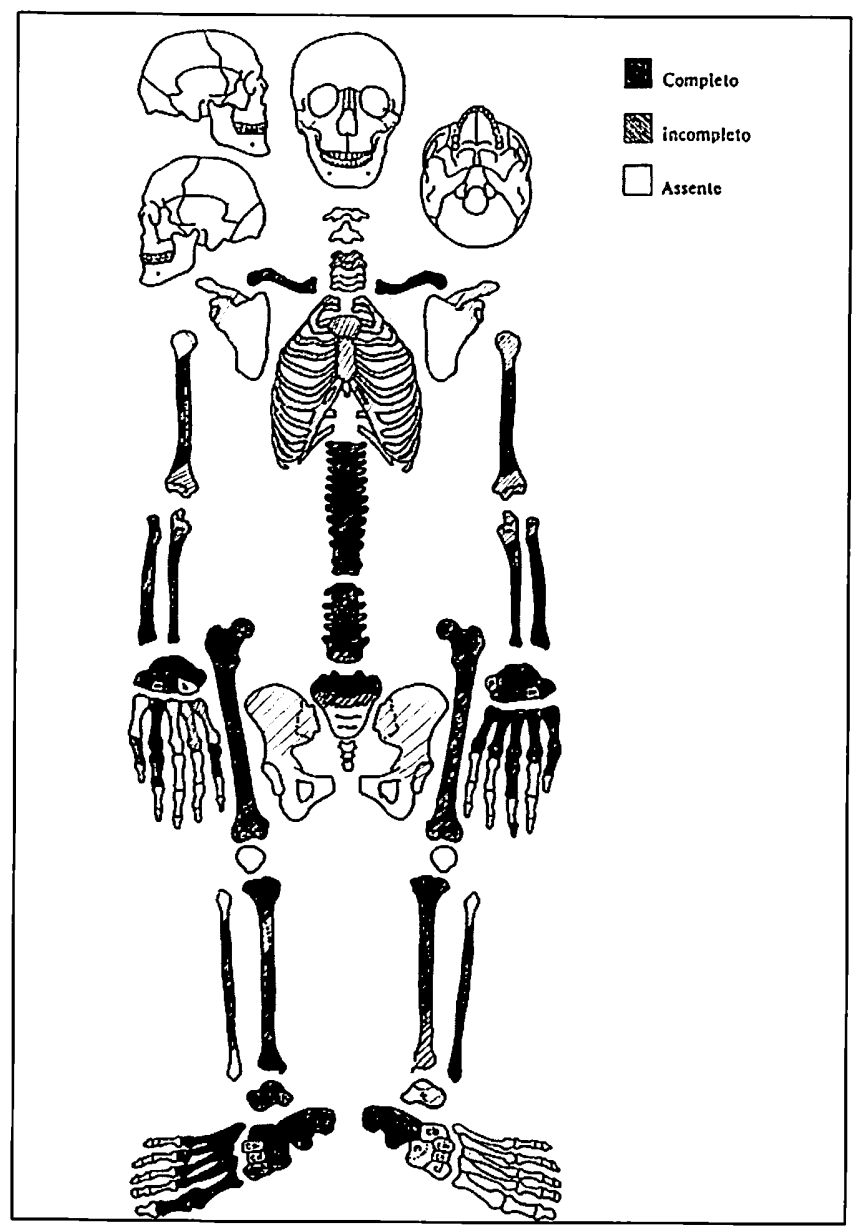

Fig. 2. State of conservation of the skeleton of tomb 57. 


\section{G. Bocchini, M.G. Belcastro}

post mortem. The skeleton showed scoliosis (Fig. 3) and dislocation of the right hip, that caused an ambulatory deficit. Fractures of the right humerus and radium, and of left ulna (parry fracture) attributable to interpersonal violence (Fig. 4) were also observed.

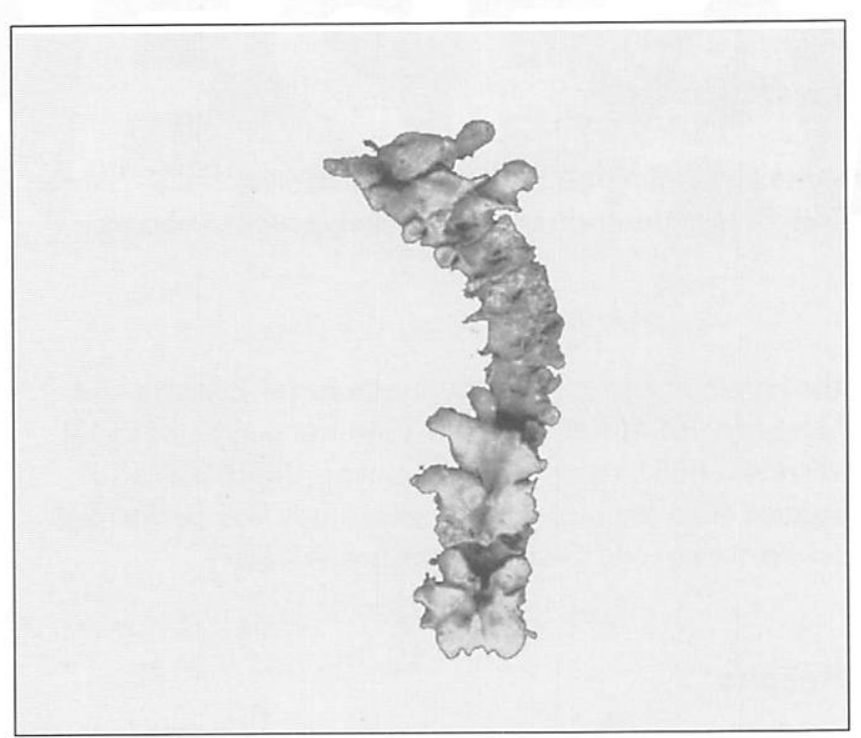

Fig. 3. Scoliosis.

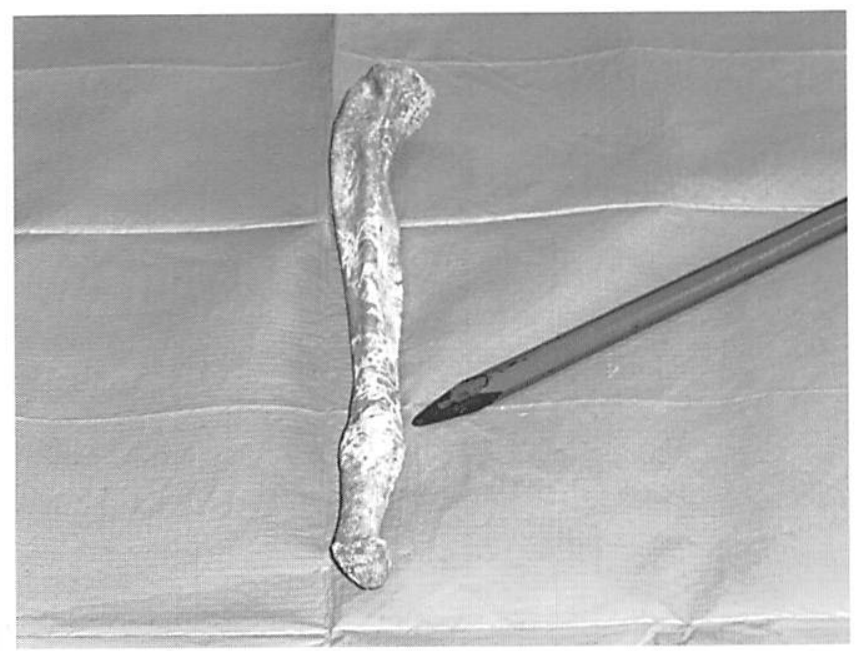

Fig. 4. Left ulna with "parry fracture".

\section{Discussion}

A whole analysis has to be performed to correctly interpret archaeological and anthropological evidences of the necropolis but the marginal position of the burial and the superficial position of the skeleton, could indicate a particular social role of the individual.

A detailed analysis of the graves distribution in the medieval cemeteries was carried out by Kiszely (1979) in relation to the social role of the individuals. In the case of t. 57 also the absence of some parts of the skeleton, the ambulatory deficit and the interpersonal violence allowed us for hypothesizing a particular social role of the individual also after death (cf. Murphy, 2008; Belcastro and Ortalli, 2010).

\section{References}

Belcastro M.G., Bonfiglioli B., Mariotti V. 2003. II Popolamento del territorio di Campochiaro in epoca altomedievale. I dati antropologici della necropoli di Vicenne. In: I Longobardi dei Ducati di Spoleto e Benevento. Spoleto 20-23 ottobre 2002, Benevento 24-27 ottobre 2002. Atti del XVI Congresso Internazionale di Studi sull'Alto Medioevo. Ed. Fondazione Centro Italiano di Studi sull'Alto Medioevo. Spoleto. 10091029.

Belcastro M. G., Ortalli J. 2010. Sepolture anomale. Indagini archeologiche e antropologiche dall'epoca classica al Medioevo in Emilia-Romagna. Giornata di studi (Castelfranco Emilia, 19 dicembre 2009), Quaderni di Archeologia dell'Emilia-Romagna, 28,All'Insegna del Giglio.

Belcastro M.G., Rastelli E., Mariotti V. 2008. Variation of the degree of sacral vertebral body fusion in adulthood in two European modern skeletal collections. Am. J. Phys. Anthropol., 135: 149160.

Buikstra J.E., Ubelaker D.H. 1994. Standards for data collection from human skeletal remains. Arkansas Archeological Survey Research Series, 44.

Fornaciari G., Giuffra V. 2009. Lezioni di Paleopatologia, Edizioni Culturali Internazionali Genova (ECIG), Genova.

Kiszely I. 1979. The anthropology of the Lombards. Bar International, 61.

Lovell N.C. 1997. Trauma analysis in Paleopatology. Yearbook of Physical Anthropology, 40: 139-170.

Murphy E. M. 2008. Deviant burial in the archaeological record, Oxbow Books, Oxford. 